\title{
Teraflop computer hits a Republican nerve
}

Washington. The semiconductor company Intel, best known as the producer of microchips for personal computers, is to build what it describes as the world's most powerful computer under a \$50-million agreement announced last week by Hazel O'Leary, the US Secretary of Energy.

The machine will use about 9,000 of Intel's next-generation microprocessor, the P6, to deliver 1.8 teraflops -1.8 million million floating-point operations per second - of computing power. It is to be built at the Sandia National Laboratory, which is run by Sandia on behalf of the Department of Energy, and should be operating by the end of next year on Sandia's main site at Albuquerque, New Mexico.

"It's exciting we can create a system ten times more powerful than the fastest supercomputer in the world today using the same chips we'll be putting into desktop PCs," says Andrew Grove, Intel's chief executive.

Although the computer is primarily intended for use by nuclear weapons designers to simulate nuclear explosions, Sandia officials say that it will be available for much of the time to other energy department scientists working on problems that require large amounts of computer power.

O'Leary made the announcement in Congress immediately before a joint hearing of two House of Representatives subcommittees into the future of the network of laboratories, which employ 59,000 people.
The timing appears to have been deliberately chosen to foster tensions between her Republican opponents in Congress, who are deeply split over whether to fund this kind of collaboration between the energy department laboratories and US industry.

Steven Schiff (Republican, New Mexico), the chair of the basic research subcommittee of the House science committee, whose district contains the Sandia laboratory, warmly welcomed the deal, and attacked unnamed Republican colleagues who have been dismissive of such projects.

"This is exactly the kind of partnership which some colleagues have criticized, many of them calling it corporate welfare," said Schiff. In his view, however, the agreement was "exactly what we need", and will benefit both US industry and the laboratories.

But Dana Rohrabacher (Republican, California), chair of the energy and environment subcommittee, which held last week's hearing jointly with Schiff's committee, is one of those who has branded technology agreements as corporate welfare, and sought to eliminate their funding (see Nature 376, 106; 1995).

The new teraflop computer is the first machine to be ordered under the energy department's new, ten-year Accelerated Strategic Computer Initiative (ASCI). Having decided that the computer would be built at Sandia, the department invited all the leading supercomputer suppliers -

\section{X-rays, not radium, may have killed Curie}

Paris. Marie Curie's final illness and death from the effects of radiation may have been due to her use of radiography during the First World War, and not, as generally believed, to exposure to radium, the element she discovered.

An opportunity to carry out an analysis of the radiation levels of her remains arose earlier this year, when Curie (right) became the first woman to be given France's highest honour, burial in the national mausoleum, the Panthéon (see Nature 374, 751; 1995).

Because of concern about the possibility of radioactivity escaping from the corpse, her exhumation was carried out under the control of the French Office de Protection contre les Rayonnements lonisants (ORPI).

Curie's body was found to be enclosed in a wooden coffin, surrounded by a lead coffin, which itself was inside a further wooden coffin. ORPI found that the level of ra-diation caused by radium within the interior coffin was, at 360 becquerels per cubic metre, significantly higher than the $13 \mathrm{~Bq} \mathrm{~m}{ }^{-3}$ found at the entrance to the cemetery.

But the level was still well below the maximum accepted safe levels of public \& exposure to radium of 害 $7,000 \mathrm{~Bq} \mathrm{~m}^{-3}$. Given that $\times$ the half-life of radium is 1,620 years, ORPI has concluded that Curie could not have been exposed to lethal levels of radium while she was alive.

Although Curie's laboratory was highly contaminated with radium, an

ORPI official points out that radium poses risks only if it is ingested either orally or through the skin.

ORPI therefore speculates that Curie's illness was more likely to have been due to her use of radiography during the First World War, when precautions to protect against $X$-rays had not yet been introduced.

D. B. including Cray and IBM - to bid for it.

But Intel was always considered to be a strong contender, as its parallel processing machines are already established at Sandia. A spokesperson for Cray, the world's leading supercomputer supplier, said it was "not

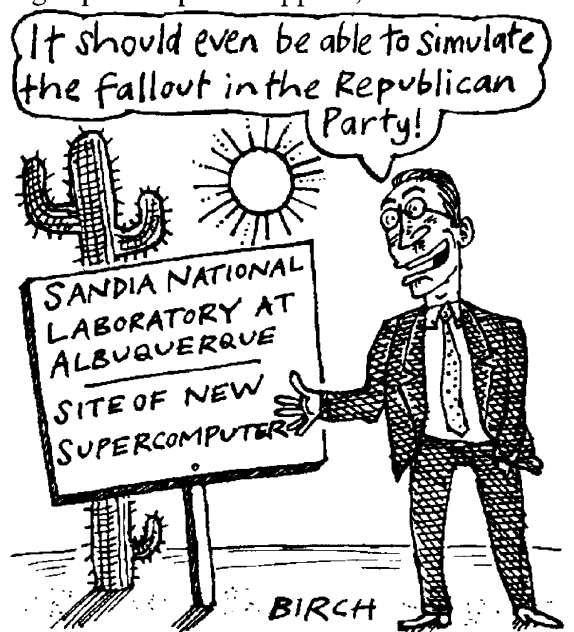

surprised at the outcome", but expected to fare better when contracts for future ASCI machines are placed at other laboratories.

European and Japanese computer suppliers have long complained that the US government uses direct subsidies to boost the global dominance of the US supercomputer industry, and this deal will do little to reassure them. All the money comes from the US nuclear weapons programme. But O'Leary left little doubt last week that a main objective is to reinforce US industrial dominance. "The US is known for its leadership in several technology areas," she said. "One of them is supercomputing. If we were not to aggressively 'push the envelope', the US would stand to lose its leadership."

House Republicans appeared to be in some disarray at the subsequent hearing about how best either to reform or reduce the Department of Energy laboratory system, lending comfort to those who are hoping the network can survive basically intact.

Bob Galvin, chairman of Motorola, and principal author of a highly critical report on the laboratories published earlier this year, called again for their "corporatization", a process under which a panel of trustees from industry and academia would operate each of the laboratories on a block grant from Congress.

But some committee staff say that Galvin's apparent belief in the innate superiority of businessmen over congressmen in taking strategic decisions did not go down well with committee members.

Even the conservative Rohrabacher ridiculed Galvin's vision, pointing out that if Congress were to entrust private businessmen with looking after public funds, they would soon be "taking money out of here by the wheelbarrow load". Colin Macilwain 